Journal of Teaching and Learning with Technology, Vol. 4, No. 1, June 2015, pp. 69-72.

doi: 10.14434/jotlt.v4n1.13114

\title{
Pinterest as a Teaching Tool
}

\author{
Sarah E. Schoper ${ }^{1}$ \\ Keywords: Pinterest, disruptive innovation, student engagement, educational \\ technology
}

\section{Framework}

This redesigned student affairs course is taught at the end of the second year in a two-year masters-level program. Students graduating from the program acquire various student affairs professional positions throughout institutions of higher education including residence life, academic advising, student activities and leadership, judicial, campus recreation, and admissions staff positions. The course focuses on understanding and considering ways to take disruptive innovation theory and put it into practice as student affairs professionals within higher education. Innovation has historically disrupted the shaping of higher education, and in many ways innovation is what those within higher education today are being asked to engage in through the accountability pressures they are experiencing (Cohen \& Kisker, 2010; Schmidtlein \& Berdahl, 2011). For example, pressure exists for institutions of higher education to meet the needs of increasingly diverse students, while also maintaining affordable costs. Innovating processes and practices within higher education is a way to respond to such pressures. Examples of disruptive innovation from the past include the credit hour and the academic calendar structure (Christensen \& Eyring, 2011). More recently, advancements in technology are perhaps the most easily identifiable way the structure of higher education is being disrupted by an innovation (Straumsheim, 2013). The assignment for the course discussed in this article derived from a desire for students to become comfortable with incorporating the process of disruptive innovation into their practice so that they are prepared professionally for change within higher education.

\section{Making It Work}

Drawing associations between seemingly distinct processes can lead to innovative ideas that have the potential to disrupt the daily processes of higher education or any organization. The ability to associate is one of five skills identified as belonging to those who are disruptive innovators (Dyer, Gregersen, \& Christensen, 2011). Association is connecting, "wildly different ideas, objects, services, technologies, and disciplines to dish up new and unusual innovations" (Dyer et al., 2011, p. 45). Thus, to help students strengthen their association skills so that they can bring innovation to higher education Pinterest was selected as a means for a biweekly assignment.

Pinterest "is a visual discovery tool that you can use to find ideas for all your projects and interests" (Pinterest, 2014). According to Popolo (2013), some of the most intriguing ways to use Pinterest include asking for donations, listing house rentals, raising awareness about various causes, and advertising casting calls, although the application is more commonly used for recipe sharing, photography, and crafting. Pinterest can be used privately or publically at an individual

\footnotetext{
${ }^{1}$ Assistant Professor, College Student Personnel Program, Western Illinois University, se-schoper@wiu.edu
} 
or community level, and is available at no cost to users globally. Essentially, Pinterest involves the process of creating virtual bulletin boards, known as "grub boards" to which users can pin resources and items of interest as "visual bookmarks" (Pinterest, 2014). Boards can be thematized, and multiple or singular users can contribute to their creation. Any item found on the Internet, including those pinned to others' grub boards, or electronically created by the user, can be pinned and shared on one or more electronic grub boards. Users are also able to provide a 500-character description under each pin.

An account and online access is required to use Pinterest. Pinterest can be used to engage various populations around the globe (e.g., student affairs professionals) by following public boards and individual users. Users can also indicate interest in, or that they "like", a pin by selecting a heart icon at the top of each pin, as well as comment underneath others' pins. One example of an educator using Pinterest is Don Phelps (2014) who used Pinterest to create a board of "Books Worth Reading". Another example is Karen Burns (2014) who created an "Ideas for HS Teachers" board to share technology applications designed to assist educators. Considering social media applications in general, Davis (2014) discusses the promising results of using applications, such as Pinterest, as learning tools by noting how they assist in teaching students how to communicate professionally online.

\section{Process}

Students were asked to create a Pinterest account, and establish a personal public board titled: "(Name) Innovating Student Affairs". As the instructor, I followed each of their boards, and invited them to contribute to the class's community board titled, "Innovating Student Affairs". Biweekly, the students were to make five pins to their personal board, and then to make one unique pin on the class's community board. Specifically, they were asked to make the following kinds of pins throughout the semester: quotes, news articles, videos, books, photos, blogs, and songs. For each pin, students were instructed to consider the week's reading and class discussion topic, and pin items they saw as connected. The students were also required to describe the connections they saw in the description box underneath each pin, and to comment on the pins of their classmates. I reviewed all of their pins prior to class, and incorporated them into the class lesson plans.

\section{Results}

Students created their own boards, and contributed to the class board, which now serves as resources for the students as they transition into their new professional roles post graduation. The board is also a resource to users who followed the board from around the globe. Throughout the course of the semester, the class community board acquired over 115 followers, and many students indicated that they received new followers to their personal boards, as well as to their profile, because of their participation in the community board. Networking is a part of the job search process, and the students enrolled in the course were searching for their first post-graduation position. Thus, an unexpected benefit of using Pinterest was that it helped market students to those who followed the community and individual boards.

Students were evaluated on making their pins by the assignment deadline, adhering to the pin categories (e.g., quotes, videos, etc.), and the potential for their pins to contribute to the field

Journal of Teaching and Learning with Technology, Vol. 4, No. 1, June 2015. jotlt.indiana.edu 
of student affairs, which they were asked to describe in each pin's description box. Using Pinterest to explore disruptive innovation provided students:

- Opportunities to take quotes, videos, news articles, etc. of interest to them outside of higher education and seek associations between them and their work within higher education;

- The chance to explain to followers how making an innovative association can benefit their practice; and

- The chance to learn how to use a web-based technology application to engage with others on a global-level and as a resource to inform student affairs practice.

\section{Future Implications}

Going forward, using all the features within the Pinterest application has potential to broaden the use of Pinterest across educational levels and content areas. Pinterest provides a way for students to engage with others inside and outside of the classroom, while also creating an established resource connected to the course topic. Related to the use of Pinterest discussed previously, and based on the experiences students shared, I am currently incorporating several changes. Many students were unfamiliar with the application at the beginning of the semester, and although I encouraged them to experiment on the site in order to be comfortable with it, they were apprehensive. Thus, it took some time before providing descriptions, liking pins, and commenting on their peers' contributions became habitual. Also, I will ask students to advertise their boards to others in the field, in an effort to enhance their networking skills, as well as increase the number of connections to other Pinterest users who might find the boards useful. Finally, I will add to the assignment the task of finding a way to use the Pinterest application as a tool to innovate their practice, outside of the two boards required for class, so that trying out their ideas would add depth to the innovative skills they are developing.

\section{References}

Burns, K. (2014). Retrieved from http://www.pinterest.com/kbklibrary/

Christensen, C. M., \& Eyring, H. J. (2011). The innovative university: Changing the DNA of higher education from the inside out. San Francisco, CA: Jossey-Bass.

Cohen, A. M., \& Kisker, C. B. (2010). The shaping of American higher education: Emergence and growth of the contemporary system. San Francisco, CA: Jossey-Bass.

Davis, V. (2014, April 13). A guidebook for social media in the classroom. Edutopia, Retrieved from: http://www.edutopia.org/blog/guidebook-social-media-in-classroom-vicki-davis

Dyer, J., Gregersen, H., \& Christensen, C.M. (2011). The innovator's dna: Mastering the five skills of disruptive innovators. Boston, MA: Harvard Business Review Press.

Phelps, D. W. (2014). Retrieved from: http://www.pinterest.com/dwphelps/

Journal of Teaching and Learning with Technology, Vol. 4, No. 1, June 2015. jotlt.indiana.edu 
Schoper, S.

Pinterest. (2014). Retrieved from: http://www.pinterest.com

Popolo, M. (2013, July). The most intriguing new ways to use Pinterest. Retrieved from: http://www.pcmag.com/slideshow/story/312534/the-10-most-intriguing-new-ways-to-usepinterest

Schmidtlein, F. A., \& Berdahl, R. O. (2011). Autonomy and accountability: Who controls academe? In P. G. Altbach, P. J. Gumport, \& R. O. Berdahl (Eds.), American higher education in the twenty-first century: Social, political, and economic challenges (pp. 69-87). Baltimore, MD: The Johns Hopkins University Press.

Straumsheim, C. (2013, October 24). Degrees of Disruption. Inside Higher Ed. Retrieved from: http://www.insidehighered.com/news/2013/10/24/analysis-suggests-moocs-will-be-moredisruptive-open-access-journals - sthash.TqQ9KZnN.dpbs

Journal of Teaching and Learning with Technology, Vol. 4, No. 1, June 2015. jotlt.indiana.edu 